\title{
Footprint areas of pollen from alder (Alnus) and birch (Betula) in the UK (Worcester) and Poland (Wrocław) during 2005-2014
}

\author{
Carsten Ambelas Skjøth ${ }^{1 *}$, Daria Bilińska², Małgorzata Werner' ${ }^{1}$, Małgorzata Malkiewicz ${ }^{3}$, Beverley Adams- \\ Groom ${ }^{1}$, Maciej Kryza², Anetta Drzeniecka-Osiadacz ${ }^{2}$ \\ 'National Pollen and Aerobiological Research Unit, Institute of Science and the Environment, University of Worcester, Henwick Grove, WR2 6AJ, Worcester, United Kingdom \\ 2 Department of Climatology and Atmosphere Protection, University of Wrocław, Aleksandra Kosiby 8, 51-621 Wrocław, Poland \\ ${ }^{3}$ Laboratory of Paleobotany, Department of Stratigraphical Geology, Institute of Geological Sciences, University of Wrocław, Cybulskiego 30, 50-205 Wrocław, Poland
}

\begin{abstract}
In this study we analyzed daily pollen concentrations of Alnus spp. and Betula spp. from Worcester, UK and Wrocław, Poland. We analyzed seasonality, annual pollen index and footprint areas for the observed pollen concentrations by using the trajectory model hybrid single particle Lagrangian integrated trajectory (HYSPLIT). We examined 10 years of data during the period 2005-2014 and found substantial differences in the seasonality, pollen indices and footprint areas. For both genera, concentrations in Wrocław are in general much higher, the seasons are shorter and therefore more intense than in Worcester. The reasons appear to be related to the differences in overall climate between the two sites and more abundant sources in Poland than in England. The footprint areas suggest that the source of the pollen grains are mainly local trees but appear to be augmented by remote sources, in particular for Betula spp. but only to a small degree for Alnus spp. For Betula spp., both sites appear to get contributions from areas in Germany, the Netherlands and Belgium, while known Betula spp. rich regions in Russia, Belarus and Scandinavia had a very limited impact on the pollen concentrations in Worcester and Wrocław. Substantial and systematic variations in pollen indices are seen for Betula spp. in Wrocław with high values every second year while a similar pattern is not observed for Worcester. This pattern was not reproduced for Alnus spp.
\end{abstract}

Keywords: aeroallergens; trajectories; HYSPLIT; climate; seasonality; sources

\section{Introduction}

Pollen from Betula spp. (hereafter Betula) and Alnus spp. (hereafter Alnus) is highly allergenic [1]. Betula and Alnus belong to the Betulaceae family and the pollen from this group of trees includes significant cross reaction [2]. In Europe, Betula is both the most abundant [3] and the most important aeroallergen from the Betulaceae family [4]. However, other genera from this group also produce important aeroallergens [2,5], especially if they are present in large quantities. In Europe, the sensitization rates for both Betula and Alnus are difficult to estimate among the general population. However, a study on patients visiting specialist centers within the Global Asthma and Allergy European Network [Ga(2)Len] skin test study has shown that standard sensitization rates for Alnus were $21.2 \%, 22.8 \%$ and $16.7 \%$ for Europe, Poland and the UK, respectively. Similar numbers for Betula have been estimated at $24.2 \%, 27.7 \%$ and $19.0 \%$, respectively [6].

\footnotetext{
*Corresponding author. Email: c.skjoth@worc.ac.uk
}

Handling Editor: Agnieszka Grinn-Gofroń
Both Poland and England have been identified as areas with large amounts of pollen from both Alnus and Betula [3] and pollen from both forest and small woodlands is considered to cause high pollen concentrations observed in urban areas like Poznań [7], London [8], Worcester [9] and Kraków [10]. The use of atmospheric models for receptor studies improves understanding with respect to source areas and weather patterns during episodes [11]. Such information is relevant for both mitigation (e.g., avoiding areas with high pollen concentrations) and forecasting. Source-receptor studies on Betula have been carried out in a number of countries including Lithuania [12], Finland [13], Denmark [14-16] and the UK $[8,17]$. For Alnus, this has only been done for Worcester, UK [17]. There is therefore a clear knowledge gap with respect to source receptor studies for both Alnus and Betula in one of the most highly populated areas in Europe with high Betula pollen concentrations: Poland.

Alnus flowers earlier than Betula [18] and is very sensitive to climate change [19]. High amounts of Alnus pollen will extend the hay fever season for sensitive individuals due to the cross reactivity with Betula. Both species will respond to climate change with respect to flowering seasonality, growth location and pollen production [20]. Such responses are in 
general non-linear [21] and are related to certain thresholds in the accumulation of heat during spring [22]. As an example: there are two main flowering species of alder in Europe (grey and red alder), for which the flowering can in some years be several weeks apart while it can be synchronous in other years [23]. This illustrates that individual species have their own specific requirements with respect to pollen release during spring and that the response to climate change can differ between species in a way that is not necessarily linear. This highlights the importance of analyzing the flowering seasonality of several species in contrasting regions.

The purpose of this study was to analyze footprint areas of two of the most important spring aeroallergens in Europe: Alnus and Betula. Additionally, we analyzed typical seasonality and compared the difference in seasonality. We studied a 10 year period in two contrasting biogeographical regions: central England (Worcester), which has a maritime climate and south west Poland (Wrocław) which has a more continental climate. We also analyzed the specific climatic conditions during the period and explored differences in the pattern of the annual pollen index between the two sites.

\section{Material and methods}

\section{Pollen data, the monitoring sites and statistical analysis}

Pollen grains were collected using a volumetric spore trap of the Hirst design [24]. Observations were done in Wrocław, Poland (51.1164 N, 17.0278 E) and in Worcester, UK (52.1970 N, 2.2421 W) during 2005-2014. The trap in Worcester is located on a building $10 \mathrm{~m}$ above the ground while the trap in Wrocław is at $20 \mathrm{~m}$. The Wrocław location is in a dense, urban built-up area, while the one at Worcester is on the university campus, with significant woody vegetation, set in a suburb. Both towns are located in areas with a substantial amount of agricultural land but detailed land cover maps and tree statistics also show that the amount of woody coverage and the amount of Betula trees are substantially larger in Poland [15] compared to the UK [8]. In the UK, the tree cover is dominated by small woodlands outside large forests [17] while Poland contains substantial large forest regions [15]. A similar pattern is seen for Alnus trees [3]. The sites are described in more detail in Skjøth et al. [17] and Malkiewicz et al. [25]. Microscope slides were prepared using a basic fuchsin stain, according to the standard procedure described in detail by the British Aerobiological Federation and used for more than a decade in European countries such as Denmark [16], United Kingdom [9] and Poland [26,27]. Alnus and Betula pollen were identified to the genus level. Pollen grains at Worcester were calculated using a 12 transverses method according to Käpyla and Pentinnen [28] and then daily mean values were calculated. Alnus and Betula pollen were identified in Wrocław using 4 longitudinal transects according to Malkiewicz et al. [25]. Both methods satisfy the basic recommendation in aerobiology for the calculation of daily mean concentrations. After Skjøth et al. [8], the observations of the daily mean values were split into two groups using a threshold that corresponds to the definition of a high day of 80 grains $\mathrm{m}^{-3}$. This threshold is based on reports showing that $90 \%$ of patients with identified pollinosis report mild symptoms at this threshold. Start and end dates for each season were calculated using the $95 \%$ method as described by Goldberg et al. [29]. In this method, the start is defined as the day when $2.5 \%$ of the season's total catch has been recorded and the end occurs when $97.5 \%$ has been reached. The observed pollen data for the period 2005-2014 were organized into tables with basic summaries (Tab. 1-Tab. 4) in the same way as Kasprzyk et al. [30] and Skjøth et al. [31], and includes the following parameters: the annual pollen index, start of season, end of season, day with maximum concentration, annual number of low concentration and high concentration days and their contribution to the total catch. Mean values and standard deviations $(S D)$ were calculated by using annual values from the 10 year record. Both high pollen concentration days and low pollen concentration days were analyzed by using back-trajectories, described in the next section. Each of the summaries in Tab. 1-Tab. 4 were statistically explored. The annual summaries were tested for normality using the Shapiro-Wilk test and in the case of non-normality also using the non-parametric Kolmogorov-Smirnov test. Homogeneity of the variance was tested with the F-test and potential difference in the mean with the $t$-test. All tests were made to a confidence level of 0.05 .

\section{Back-trajectory calculations}

The observations on both high pollen concentration days and low pollen concentration days were analyzed with back trajectories in order to estimate potential source regions. Back trajectories were calculated with the HYSPLIT (hybrid single-particle Lagrangian integrated trajectory) model $[32,33]$ by using a similar approach as previous studies on Alternaria spores [31,34], Betula [16,17,35] and Ambrosia artemisiifolia (ragweed) pollen [36]. All these studies use clusters of trajectories in order to minimize the uncertainty that is associated with single trajectories [35]. Air mass trajectories were calculated 96 hours back in time with 2 hour steps between each trajectory. Trajectory calculations were made using the Global Data Analysis System (GDAS) meteorological files as input. These data are maintained by NOAA Air Resources Laboratory (ARL), with a temporal resolution of 3 hours and a spatial resolution of 1 degree $\times 1$ degree. Air mass trajectories were calculated at both observational sites. A receiving height of $500 \mathrm{~m}$ was used, which is typical for aerobiological studies of this kind that use the GDAS data set [11]. Back trajectories for each group were then organized according to their density on a $50 \times 50$ $\mathrm{km}$ grid and displayed on maps, in the same way as Skjøth et al. [17], as an indication of the footprint area. The footprint areas were then normalized so that each grid cell provided the percentage of the entire footprint area and afterwards combined into one image.

\section{Climatic analysis}

Meteorological observations were obtained from the globally coordinated network of meteorological stations that report global summary of the day (GSOD), which are exchanged under the World Meteorological Organization (WMO) World Weather Watch Programme. This includes daily values of mean, maximum and minimum temperatures. 
Tab. 1 Statistics for the observations of Alnus pollen at Worcester during the period 2005-2014 showing seasonal pollen index, day of season start, day of season end and day of maximum pollen concentration and its value.

\begin{tabular}{lccccccccc} 
Year & $\begin{array}{c}\text { Total pollen } \\
\text { Index }\end{array}$ & $\begin{array}{c}\text { Day of } \\
\text { season start }\end{array}$ & $\begin{array}{c}\text { Day of } \\
\text { season end }\end{array}$ & $\begin{array}{c}\text { Day of } \\
\text { maximum } \\
\text { concentration }\end{array}$ & $\begin{array}{c}\text { Maximum } \\
\text { value (grains } \\
\left.\mathbf{m}^{-3}\right)\end{array}$ & $\begin{array}{c}\text { Sum of } \\
\text { pollen in } \\
\text { season } \\
(\text { pollen) }\end{array}$ & $\begin{array}{c}\text { Days in } \\
\text { season } \\
(\boldsymbol{n})\end{array}$ & $\begin{array}{c}\text { Sum, low } \\
\text { days in } \\
\text { season } \\
\text { (pollen) }\end{array}$ & $\begin{array}{c}\text { Sum, high } \\
\text { days in } \\
\text { season } \\
\text { (pollen) }\end{array}$ \\
\hline 2005 & 852 & $02 / 02$ & $20 / 03$ & $10 / 03$ & 98 & 801 & 47 & 613 & 188 \\
2006 & 1399 & $04 / 02$ & $10 / 04$ & $09 / 03$ & 274 & 1331 & 66 & 723 & 608 \\
2007 & 1219 & $02 / 02$ & $28 / 03$ & $21 / 02$ & 102 & 1163 & 55 & 897 & 273 \\
2008 & 1293 & $21 / 01$ & $26 / 03$ & $29 / 02$ & 161 & 1227 & 66 & 892 & 335 \\
2009 & 2344 & $14 / 02$ & $21 / 03$ & $25 / 02$ & 365 & 2229 & 36 & 604 & 1625 \\
2010 & 770 & $09 / 02$ & $27 / 03$ & $21 / 03$ & 105 & 729 & 47 & 520 & 209 \\
2011 & 1904 & $30 / 01$ & $20 / 03$ & $23 / 02$ & 433 & 1799 & 50 & 650 & 1149 \\
2012 & 1399 & $15 / 02$ & $20 / 03$ & $29 / 02$ & 184 & 1331 & 35 & 391 & 940 \\
2013 & 1379 & $06 / 02$ & $11 / 04$ & $05 / 03$ & 223 & 1287 & 65 & 855 & 432 \\
2014 & 1209 & $02 / 02$ & $19 / 03$ & $07 / 03$ & 122 & 1138 & 46 & 612 & 526 \\
Mean & 1377 & $04 / 02$ & $27 / 03$ & $04 / 03$ & 207 & 1304 & 51 & 676 & 629 \\
Median & 1336 & $03 / 02$ & $23 / 03$ & $06 / 03$ & 173 & 1257 & 49 & 632 & 479 \\
$S D$ & 462 & 7 & 9 & 8 & 117 & 417 & 11 & 158
\end{tabular}

Sum of pollen within the season, sum of pollen on low concentration days and sum on high concentration days and number of days above $80 \mathrm{pm}^{-3}$ as a daily mean value. The sum of low concentration days and high concentration days correspond to the total accumulated catch during the season (2.5-97.5\% of accumulated catch).

Tab. 2 Statistics for the observations of Alnus pollen at Wrocław during the period 2005-2014 showing seasonal pollen index, day of season start, day of season end and day of maximum pollen concentration and its value.

\begin{tabular}{lccccccccc}
\hline Year & $\begin{array}{c}\text { Total pollen } \\
\text { Index }\end{array}$ & $\begin{array}{c}\text { Day of } \\
\text { season start }\end{array}$ & $\begin{array}{c}\text { Day of } \\
\text { season end }\end{array}$ & $\begin{array}{c}\text { Day of } \\
\text { maximum } \\
\text { concentration }\end{array}$ & $\begin{array}{c}\text { Maximum } \\
\text { value }\left(\mathbf{p m}^{-3}\right)\end{array}$ & $\begin{array}{c}\text { Sum of } \\
\text { pollen in } \\
\text { season } \\
\text { (pollen) }\end{array}$ & $\begin{array}{c}\text { Days in } \\
\text { season } \\
(\boldsymbol{n})\end{array}$ & $\begin{array}{c}\text { Sum, low } \\
\text { days in } \\
\text { season } \\
\text { (pollen) }\end{array}$ & $\begin{array}{c}\text { Sum, high } \\
\text { days in } \\
\text { season } \\
\text { (pollen) }\end{array}$ \\
\hline 2005 & 5164 & $17 / 03$ & $03 / 04$ & $28 / 03$ & 1034 & 4957 & 11 & 354 & 4603 \\
2006 & 3899 & $27 / 03$ & $08 / 04$ & $29 / 03$ & 881 & 3467 & 8 & 184 & 3283 \\
2007 & 1061 & $03 / 02$ & $25 / 03$ & $07 / 03$ & 189 & 992 & 4 & 474 & 518 \\
2008 & 5988 & $25 / 01$ & $29 / 02$ & $24 / 02$ & 484 & 5711 & 22 & 386 & 5325 \\
2009 & 1284 & $03 / 03$ & $03 / 04$ & $18 / 03$ & 204 & 1181 & 5 & 510 & 671 \\
2010 & 3904 & $17 / 03$ & $28 / 03$ & $20 / 03$ & 987 & 3740 & 9 & 76 & 3664 \\
2011 & 3277 & $26 / 02$ & $29 / 03$ & $13 / 03$ & 730 & 3084 & 10 & 282 & 2802 \\
2012 & 3002 & $29 / 02$ & $26 / 03$ & $10 / 03$ & 532 & 2845 & 8 & 440 & 2405 \\
2013 & 4882 & $05 / 03$ & $20 / 04$ & $11 / 4$ & 881 & 4441 & 11 & 569 & 3872 \\
2014 & 4575 & $10 / 02$ & $13 / 03$ & $03 / 03$ & 785 & 4333 & 19 & 479 & 3854 \\
Mean & 3704 & $31 / 01$ & $28 / 03$ & $17 / 03$ & 671 & 3475 & 11 & 375 & 3100 \\
Median & 3902 & $03 / 02$ & $29 / 03$ & $16 / 03$ & 758 & 3604 & 10 & 413 & 3474 \\
$S D$ & 1602 & 20 & 14 & 14 & 306 & 1524 & 6 & 155 & 1559 \\
\hline
\end{tabular}

Sum of pollen within the season, sum of pollen on low concentration days and sum on high concentration days and number of days above $80 \mathrm{pm}^{-3}$ as a daily mean value. The sum of low concentration days and high concentration days correspond to the total accumulated catch during the season (2.5-97.5\% of accumulated catch). 
Tab. 3 Statistics for the observations of Betula pollen at Worcester showing seasonal pollen index, day of season start, day of season end and day of maximum pollen concentration and its value.

\begin{tabular}{lccccccccc}
\hline Year & $\begin{array}{c}\text { Total pollen } \\
\text { Index }\end{array}$ & $\begin{array}{c}\text { Day of } \\
\text { season start }\end{array}$ & $\begin{array}{c}\text { Day of } \\
\text { season end }\end{array}$ & $\begin{array}{c}\text { Day of } \\
\text { maximum } \\
\text { concentration }\end{array}$ & $\begin{array}{c}\text { Maximum } \\
\text { value }(\text { grains } \\
\left.\mathbf{m}^{-3}\right)\end{array}$ & $\begin{array}{c}\text { Sum of } \\
\text { pollen in } \\
\text { season } \\
\text { (pollen) }\end{array}$ & $\begin{array}{c}\text { Days in } \\
\text { season } \\
(\boldsymbol{n})\end{array}$ & $\begin{array}{c}\text { Sum, low } \\
\text { days in } \\
\text { season } \\
\text { (pollen) }\end{array}$ & $\begin{array}{c}\text { Sum, high } \\
\text { days in } \\
\text { season } \\
\text { (pollen) }\end{array}$ \\
\hline 2005 & 2214 & $02 / 04$ & $05 / 05$ & $22 / 04$ & 464 & 2125 & 34 & 743 & 1382 \\
2006 & 7457 & $17 / 04$ & $09 / 05$ & $23 / 04$ & 1069 & 7004 & 23 & 33 & 6971 \\
2007 & 2985 & $04 / 04$ & $29 / 04$ & $12 / 04$ & 443 & 2833 & 26 & 356 & 2477 \\
2008 & 3154 & $04 / 04$ & $07 / 05$ & $22 / 04$ & 738 & 2992 & 34 & 811 & 2181 \\
2009 & 2628 & $01 / 04$ & $01 / 05$ & $15 / 04$ & 278 & 2505 & 31 & 428 & 2077 \\
2010 & 4632 & $10 / 04$ & $07 / 05$ & $18 / 04$ & 1032 & 4475 & 28 & 323 & 4152 \\
2011 & 3103 & $29 / 03$ & $29 / 04$ & $06 / 04$ & 598 & 2940 & 32 & 399 & 2541 \\
2012 & 3026 & $25 / 03$ & $01 / 05$ & $29 / 03$ & 351 & 2608 & 38 & 704 & 1904 \\
2013 & 3016 & $23 / 04$ & $17 / 05$ & $25 / 04$ & 434 & 2897 & 25 & 354 & 2543 \\
2014 & 5845 & $29 / 03$ & $25 / 04$ & $02 / 04$ & 528 & 5663 & 28 & 117 & 5546 \\
Mean & 3806 & $05 / 04$ & $04 / 05$ & $14 / 04$ & 594 & 3604 & 30 & 427 \\
Median & 3064 & $03 / 04$ & $03 / 05$ & $16 / 04$ & 496 & 2919 & 30 & 378 & 3177 \\
$S D$ & 1688 & 9 & 6 & 10 & 300 & 1512 & 4 & 244
\end{tabular}

Sum of pollen within the season, sum of pollen on low concentration days and sum on high concentration days and number of days above $80 \mathrm{pm}^{-3}$ as a daily mean value. The sum of low concentration days and high concentration days correspond to the total accumulated catch during the season (2.5-97.5\% of accumulated catch).

Tab. 4 Statistics for the observations of Betula pollen at Wrocław during the period 2005-2014 showing seasonal pollen index, day of season start, day of season end and day of maximum pollen concentration and its value.

\begin{tabular}{lccccccccc}
\hline Year & $\begin{array}{c}\text { Total pollen } \\
\text { Index }\end{array}$ & $\begin{array}{c}\text { Day of } \\
\text { season start }\end{array}$ & $\begin{array}{c}\text { Day of } \\
\text { season end }\end{array}$ & $\begin{array}{c}\text { Day of } \\
\text { maximum } \\
\text { concentration }\end{array}$ & $\begin{array}{c}\text { Maximum } \\
\left.\text { value }(\mathbf{p m})^{-3}\right)\end{array}$ & $\begin{array}{c}\text { Sum of } \\
\text { pollen in } \\
\text { season } \\
\text { (pollen) }\end{array}$ & $\begin{array}{c}\text { Days in } \\
\text { season } \\
(\boldsymbol{n})\end{array}$ & $\begin{array}{c}\text { Sum, low } \\
\text { days in } \\
\text { season } \\
\text { (pollen) }\end{array}$ & $\begin{array}{c}\text { Sum, high } \\
\text { days in } \\
\text { season } \\
\text { (pollen) }\end{array}$ \\
\hline 2005 & 5037 & $12 / 04$ & $29 / 04$ & $17 / 04$ & 1626 & 4798 & 12 & 358 & 4440 \\
2006 & 16038 & $19 / 04$ & $08 / 05$ & $22 / 04$ & 2368 & 15130 & 18 & 7 & 15123 \\
2007 & 4633 & $07 / 04$ & $25 / 04$ & $15 / 04$ & 1322 & 4432 & 11 & 283 & 4149 \\
2008 & 10194 & $08 / 04$ & $03 / 05$ & $20 / 04$ & 1452 & 9713 & 21 & 218 & 9495 \\
2009 & 3936 & $07 / 04$ & $25 / 04$ & $08 / 04$ & 1317 & 3791 & 8 & 385 & 3406 \\
2010 & 9592 & $09 / 04$ & $29 / 04$ & $16 / 04$ & 1779 & 8936 & 17 & 161 & 8775 \\
2011 & 4573 & $05 / 04$ & $30 / 04$ & $11 / 04$ & 843 & 4428 & 14 & 256 & 4172 \\
2012 & 15444 & $04 / 04$ & $29 / 04$ & $18 / 04$ & 1807 & 14643 & 21 & 184 & 14459 \\
2013 & 5738 & $19 / 04$ & $29 / 04$ & $23 / 04$ & 1378 & 5543 & 7 & 90 & 5453 \\
2014 & 13491 & $30 / 03$ & $24 / 04$ & $08 / 04$ & 2247 & 12926 & 18 & 275 & 12651 \\
Mean & 8868 & $09 / 04$ & $29 / 04$ & $16 / 04$ & 1614 & 8434 & 15 & 222 & 8212 \\
Median & 7665 & $08 / 04$ & $29 / 04$ & $17 / 04$ & 1539 & 7240 & 16 & 237 & 7114 \\
$S D$ & 4755 & 6 & 4 & 6 & 457 & 4480 & 5 & 116 & 4549 \\
\hline
\end{tabular}

Sum of pollen within the season, sum of pollen on low concentration days and sum on high concentration days and number of days above $80 \mathrm{pm}^{-3}$ as a daily mean value. The sum of low concentration days and high concentration days correspond to the total accumulated catch during the season (2.5-97.5\% of accumulated catch). 
We used data from stations at Pershore $\left(52.150^{\circ} \mathrm{N}, 2.033^{\circ} \mathrm{W}\right)$, near Worcester, and Wrocław $\left(51.117^{\circ} \mathrm{N}, 16.883^{\circ} \mathrm{E}\right)$ and analyzed maximum and mean temperatures using box plots. We analyzed each year during the period January-May and during the pollen season for Alnus and Betula, respectively. Temperatures were analyzed statistically as described in section "Pollen data, the monitoring sites and statistical analysis".

\section{Results}

\section{Main observational record}

The annual pollen index of Alnus in Worcester (Tab. 1) and Wrocław (Tab. 2) varied by almost a factor of 3 and a factor of 6 among the considered years, respectively. The mean seasonal index was almost a factor of 4 higher in Wrockaw than in Worcester and the $S D$ was also higher. Nevertheless, the seasonal pollen index was lower in Wrockaw for the two years 2007 and 2009. The mean start dates were the end of January or the beginning of February, but Worcester had a $S D$ of 7 days, while for Wrocław it was 20 days. A similar pattern was seen for the high concentration days and the end of the season. Concentrations on high days were about a factor of 3 higher in Wrocław compared to Worcester. This was contrasted by a generally shorter season in Wrocław (30 days) compared to Worcester (51 days). In fact, the pollen season in Wrocław was shorter for each of the investigated 10 years. These differences are generally found to be statistically significant with $P$ values ( $t$-test) below 0.0013 .

The annual pollen index of Betula in Worcester (Tab. 3) and Wrocław (Tab. 4) varied by a factor of about 3 to 5 among the considered years. The mean seasonal index and $S D$ was more than double in Wrocław compared to Worcester. The mean start dates were the beginning of April, with similar variation $(S D)$ at both sites. A similar pattern was seen for the high days and the end of the pollen season, where the end occurred later in Worcester. Concentrations on high days are about a factor of 2 higher in Wrocław compared to Worcester. This was contrasted by a generally shorter season in Wrocław (15 days) compared to Worcester (30 days). These differences are generally found to be statistically significant with $P$-values ( $t$-test) below 0.0398 .

The annual pollen index for Betula in Wrocław had a marked biennial rhythm around the mean value for the entire period. This clear rhythm is not seen for Alnus in Wrocław or for any of the species in Worcester. This rhythm in the annual pollen index in Wrocław manifests itself in a way that every second year the annual pollen index is smaller than the mean value for the entire period. In all the other years the annual pollen index is larger than the mean value for the entire period.

\section{Footprint areas}

The footprint areas (Fig. 1) show a generally westerly orientation for Alnus for the high pollen concentration days (Fig. 1a), particularly for Worcester with almost no overlap of the footprint areas for the two sites. This is in contrast to the general air mass pattern during the season (Fig. 1c) that shows an east-west pattern and some overlap. The footprint area for Betula shows a narrow east-west orientation covering
Germany, Netherlands, northern France and Belgium (Fig. 1b) with some overlap of the two sites. The general air mass patterns during the season (Fig. 1d) show a wider east-west pattern than for the high concentration days, with a fraction of air masses originating from a more northern orientation. The footprint areas on the high concentration days have no connection to Scandinavia or Russia for both pollen genera and hardly any connection to Belarus and the Baltic countries.

\section{Climate and meteorology during the pollen seasons}

The climate between the two sites (Fig. 2e) clearly shows large variations in mean temperatures in Wrocław and smaller variations in Worcester (Pershore site). In fact, the variation has been larger in Wrocław every year during the 10 year period. The largest variations are also seen during the pollen season for Wrocław, but only for selected years (e.g., 2012), with an opposite picture for the rest (e.g., 2005). Similarly, the mean values during the Alnus season show a diverse picture for both mean (Fig. 2a) and maximum temperatures (Fig. 2c) supported by the fact that the difference is not statistically significant. During the Betula season there is also a diverse picture for the mean temperatures (Fig. 2d), again supported by the fact that the difference is not statistically significant. The mean value of daily maximum temperatures, however, was always larger for Wrocław (Fig. 2b).

\section{Discussion and conclusion}

Our investigation shows that there are considerable differences in the source-receptor relationships between Wrocław and Worcester and that these differences vary between Alnus and Betula. The timing of the start of the season is more or less similar for the two sites and for both species. This suggests that the differences seen between the two sites are not related to parameters such as day-length. Instead the differences can be related to other factors such as number of trees in each region, genetic variations among the trees and environmental factors [37].

The higher pollen index in Wrocław for both tree genera can partly be attributed to Poland's more abundant sources of both Betula [16,38,39] and Alnus [40,41]. The existing source maps for these genera also show, however, that the sources are unevenly distributed in both countries, which is expected to be a major contribution to the large spatial variations in the 10 year pollen indices that previously have been observed within the two countries [3]. However, it is also clear that the footprint areas are different. For Alnus, Wrocław has a large footprint area covering regions such as Germany and Benelux, while for the UK, the footprint area appears to be mainly Wales [16]. In contrast, there is larger similarity in the footprint areas for Betula for both sites since a fraction of the air masses on the high pollen concentration days originates from Germany and the Benelux countries. The similarity of the pollen seasons suggests that sources in these regions can augment local production in both the UK and Poland. This finding supports previous findings by Estrella et al. [42] that Betula pollen concentrations 

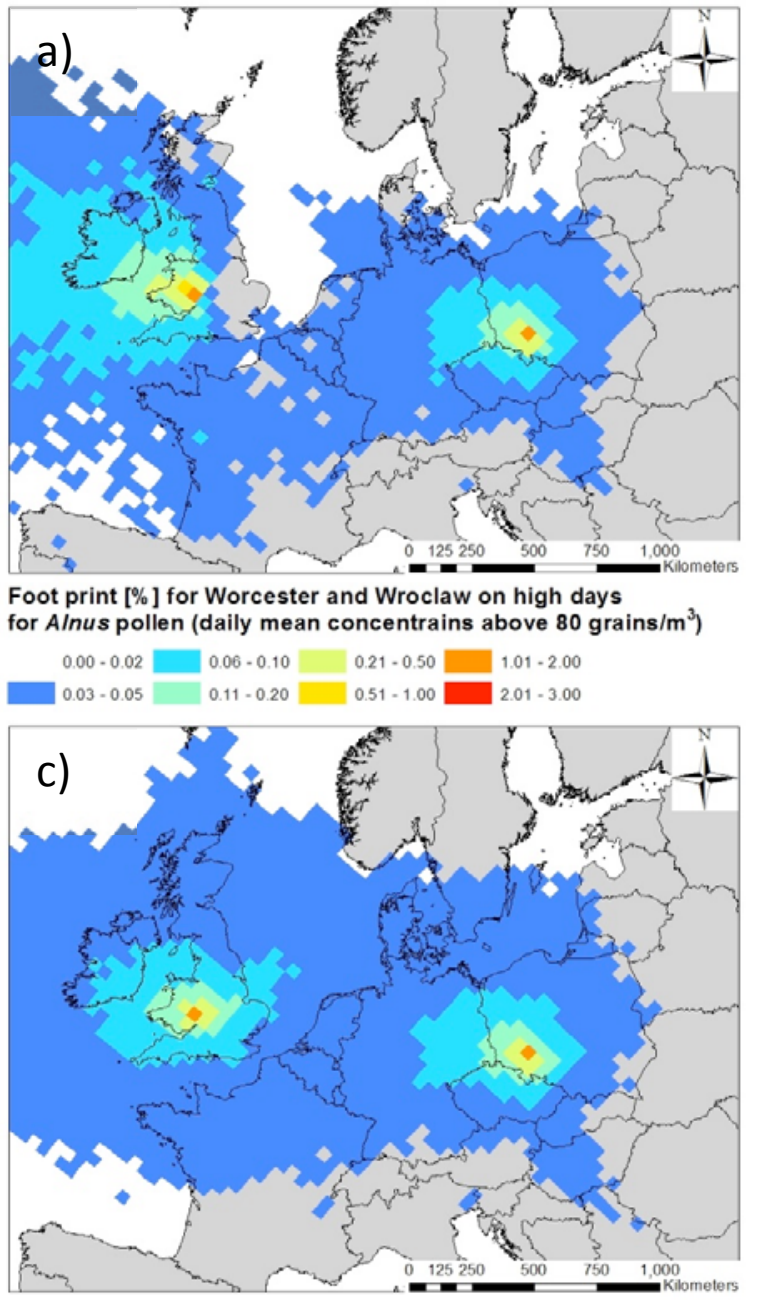

Foot print [\%] for Worcester and Wroclaw on all days with $A$ lnus pollen (daily mean concentrains above 0 grains $/ \mathrm{m}^{3}$ )

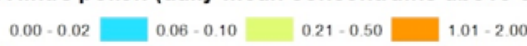

$\begin{aligned} & 0.03-0.05 \\ & 0.11-0.20\end{aligned} \quad 0.51-1.00 \square[2.01-3.00$

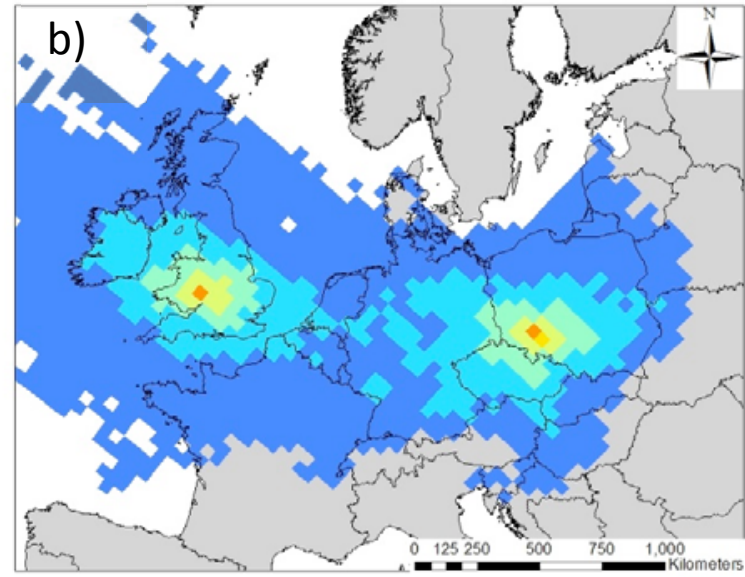

\section{Foot print [\%] for Worcester and Wroclaw on high days for Betula pollen (daily mean concentrains above 80 grains $/ \mathrm{m}^{3}$ ) $0.00 \cdot 0.02 \square 0.06 \cdot 0.10 \quad 0.21 \cdot 0.50 \square 1.01 \cdot 2.00$} \begin{tabular}{l}
$0.03-0.05 \square[0.11-0.20 \square[0.51-1.00 \square$ \\
\hline
\end{tabular}

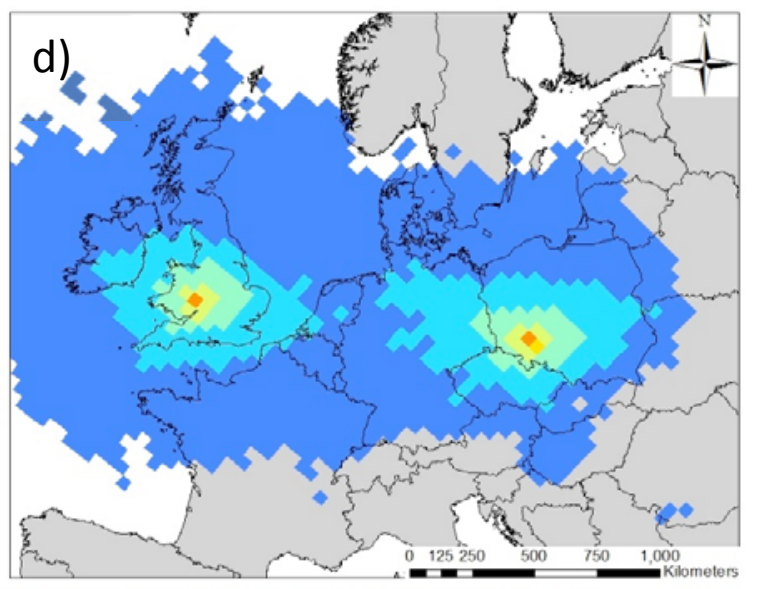

Foot print [\%] for Worcester and Wroclaw on all days with Betula pollen (daily mean concentrains above 0 grains $/ \mathrm{m}^{3}$ )

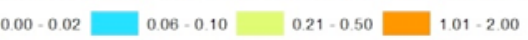

$0.03-0.05[0.11-0.20 \quad 0.51-1.00 \square[2.01-3.00$

Fig. 1 Footprint area of the trajectories for both Alnus (left) and Betula (right) pollen observations during the pollen season in Wrocław and Worcester. Top panel shows foot print area during high concentration days for Alnus (a) and Betula (b) and low panel the corresponding footprint areas for all observations of Alnus (c) and Betula (d), respectively.

showed only limited correlation with the local phenology. A substantial fraction of Betula pollen must therefore originate from more remote sources in Central Europe. Surprisingly enough, these remote sources do not appear to include Russia, Belarus, Scandinavia and the Baltic countries. These areas have previously been identified as major source regions for birch pollen $[13,14,41]$. This lack of influence is likely to be related to general air flow pattern as shown by the footprint areas. This air flow during the pollen season is mainly east and west directed. The source areas in Scandinavia, Baltic countries, Belarus and Russia are located in a more northern transect of the air flow, thus augmenting other areas such as Denmark [14], northern Germany and northern Poland [7] with pollen from remote sources.

The seasonality in the pollen concentrations is markedly different between Wrocław and Worcester. The season in Wrocław is in general shorter and more intense with large variations in start dates compared to Worcester (e.g., Betula in Tab. 2 and Tab. 4). Such differences are the characteristic feature of a continental climate (Wrocław) versus a maritime climate (Worcester). A continental climate in general has large temperature variations between winter and spring while a maritime climate has milder winters and smaller temperature gradients in between seasons. This has a direct consequence on the general behavior of the pollen season. There is a small variation in elevation above sea level between the two sites. Worcester is located on the Severn plain only about $30 \mathrm{~m}$ above sea level, while Wrocław is located 100-150 $\mathrm{m}$ above sea level. This difference is however not expected to have a substantial impact on the observed differences between the two sites. The most important parameters for the development of the pollen season from spring trees, as well as the daily release, are daily mean, daily maximum and daily minimum temperatures [42], and the heat accumulation (degree days) during or before the season $[18,21,44]$. This suggests that a continental climate will tend to have shorter 
a)

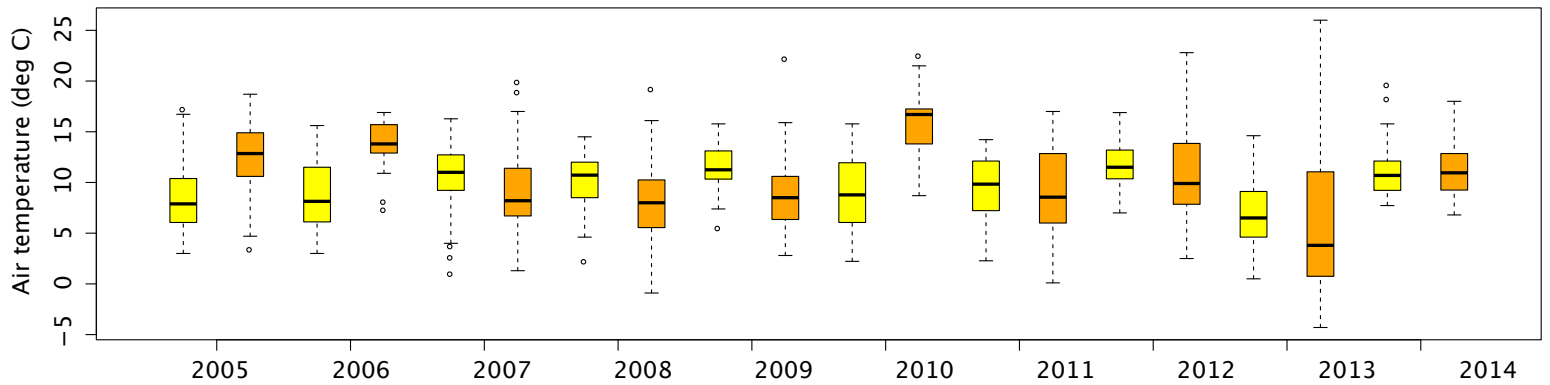

b)

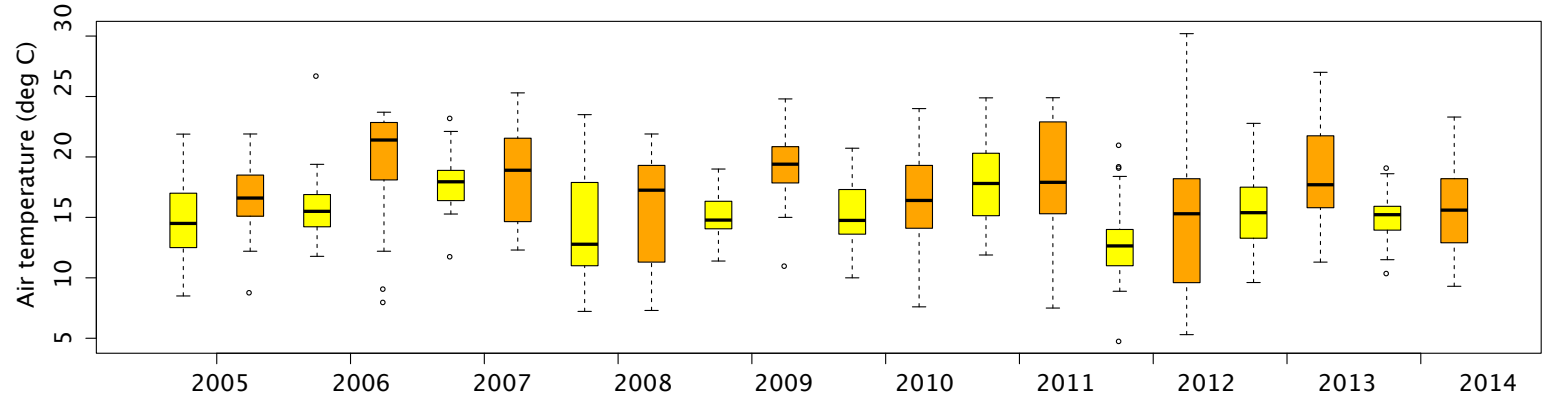

c)

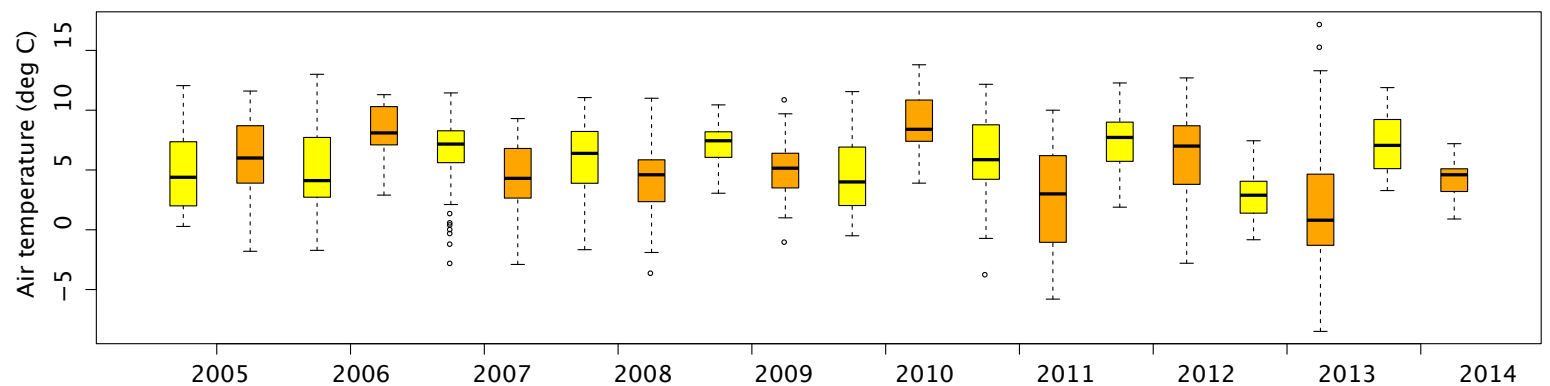

d)

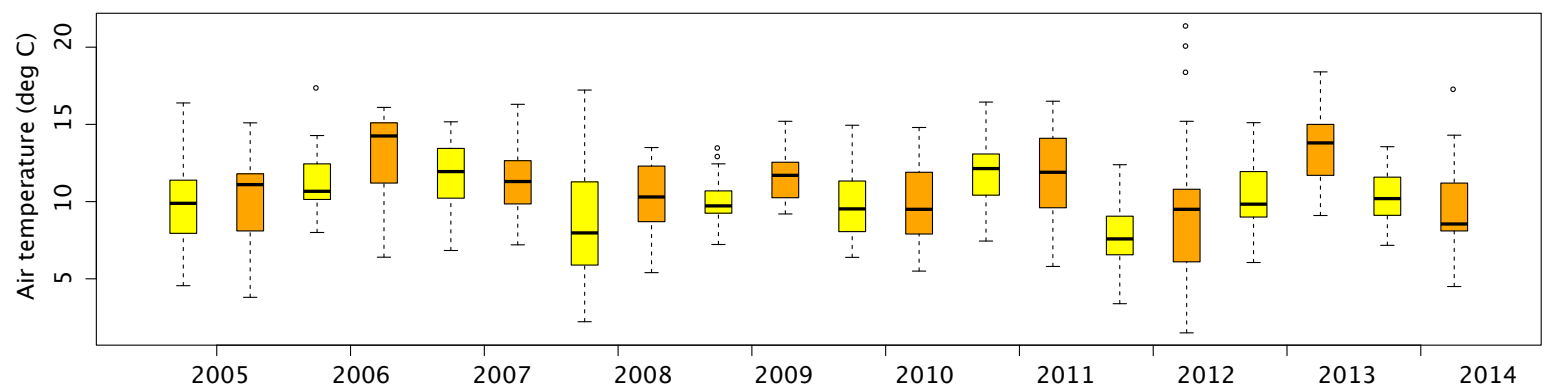

e)

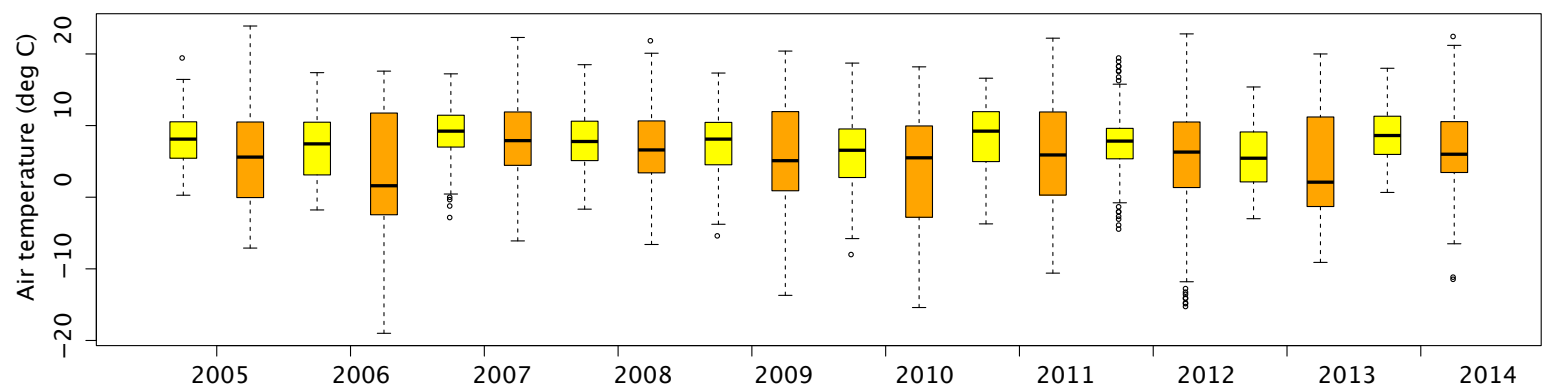

Fig. 2 Box plots showing maximum temperatures for both Alnus $(\mathbf{a}, \mathbf{c})$ and Betula $(\mathbf{b}, \mathbf{d})$ during each of the pollen seasons in Wrocław (orange) and Worcester (yellow). Top panel shows box plots for maximum temperature and middle panel for mean temperature. Lower panel shows box plots for the period January-May (e) based on mean temperatures. 
and more intense pollen seasons during spring compared to the maritime climate, which is supported by these data sets for both Alnus and Betula.

Data from both sites sets showed large variations in the annual pollen index for both Alnus and Betula. There does not appear to be a strong biennial pattern in Worcester as observed for Betula at other locations [45] as well as in Wrocław. The annual rhythm is likely related to annual variations in resource allocation within the trees in a specific region, thus a specific biological mechanism [46]. These large annual variations have previously been reported in several publications from other Polish areas such as Lublin [47] and Kraków [10]. The observed annual variations appear to be synchronised with the observations from Wrocław, suggesting that these variations are a large scale phenomena in this region. However, it is very difficult to quantify this using mechanistic models that operate on this scale, as other areas, e.g., Worcester, appear to have a less pronounced variation. This difficulty is highlighted by recent model developments

\section{Acknowledgments}

The authors acknowledge the National Oceanic and Atmospheric Administration (NOAA) for the provision of the HYSPLIT transport and dispersion model used in this publication as well as access to input data (GDAS archive) for running the HYSPLIT model. We acknowledge support from the EU European Social Fund, Operational Programme Human Capital, through funding a visiting professor position at University of Wrocław to Carsten Ambelas Skjøth (June-July 2015), contract number UDAPOKL.04.01.01-00-054/10-02. Justyna Krynicka, University of Wrocław, is acknowledged for her contribution on analyzing and organizing pollen data.

\section{Authors' contributions}

The following declarations about authors' contributions to the research have been made: all authors contributed to the writing and to the formulation of the main objectives in the study. CAS led the study, designed Fig. 1a-d and led the scientific writing; DB, MW and MK conducted model simulations with the HYSPLIT model and analyzed foot print areas (Fig. 1a-d); BAG and MM conducted observations and analyzed the observations using optical microscopes (Tab. 1-Tab. 4); ADO conceived the main idea on biometeorological information which includes pollen and air pollution; $\mathrm{MK}$ and ADO secured funding for the project.

\section{Competing interests}

No competing interests have been declared.

\section{References}

1. Ipsen $\mathrm{H}$, Lowenstein $\mathrm{H}$. Basic features of cross-reactivity in tree and grass pollen allergy. Clin Rev Allergy Immunol. 1997;15:389-396. http://dx.doi.org/10.1007/BF02737734

2. Valenta R, Breiteneder H, Pettenburger K, Breitenbach M, Rumpold $\mathrm{H}$, Kraft D, et al. Homology of the major birch-pollen allergen, Bet $\mathrm{v}$ I, with the major pollen allergens of alder, hazel, and hornbeam at the nucleic acid level as determined by cross-hybridization. J Allergy Clin Immunol. 1991;87:677-682. http://dx.doi. org/10.1016/0091-6749(91)90388-5

3. Skjøth CA, Šikoparija B, Jäger S. Pollen sources. In: Sofiev M, Bergmann KC, editors. Allergenic pollen. Dordrect: Springer; 2013. p. 9-27. http://dx.doi.org/10.1007/978-94-007-4881-1_2

4. van Ree R, van Leeuwen WA, Akkerdaas JH, Aalberse RC. How far can we simplify in vitro diagnostics for Fagales tree pollen allergy? A study with three whole pollen extracts and purified natural and recombinant allergens. Clin Exp Allergy. 1999;29:848-855. http:// dx.doi.org/10.1046/j.1365-2222.1999.00521.x

5. Gumowski PI, Clot B, Davet A, Saad S, Hassler H, Dunoyer-Geindre $\mathrm{S}$. The importance of hornbeam (Carpinus sp.) pollen hypersensitivity on Betula stating that the annual variations in pollen production is one of the knowledge gaps in current forecasting methods [48]. Previous findings in relation to climate change and increasing temperatures have also identified knowledge gaps in relation to the forecast of the Betula pollen season, while studies on Alnus are much scarcer. Different species have different responses to environmental factors and in particular climate change [19]. In Europe a large number of species contribute to the pollen load of Betula and Alnus [3]. However, studies focusing on forestry statistics suggest that in large areas of Europe, the four dominant species are Betula pubescence, Betula pendula, Alnus glutinosa and Alnus incana [41]. Simultaneous studies on several species or genera from the Betulaceae family, as in this case, could therefore be expected to decrease such knowledge gaps, which ultimately will benefit both forecasting in aerobiology and knowledge about tree species and their adaptation to climate change.

in spring allergies. Aerobiologia. 2000;16:83-86. http://dx.doi. org/10.1023/A:1007600313862

6. Burbach GJ, Heinzerling LM, Edenharter G, Bachert C, Bindslev-Jensen C, Bonini S, et al. GA(2)LEN skin test study II: clinical relevance of inhalant allergen sensitizations in Europe. Allergy. 2009;64:1507-1515. http://dx.doi.org/10.1111/j.1398-9995.2009.02089.x

7. Grewling Ł, Jackowiak B, Nowak M, Uruska A, Smith M. Variations and trends of birch pollen seasons during 15 years (1996-2010) in relation to weather conditions in Poznań (western Poland). Grana. 2012;51:280-292. http://dx.doi.org/10.1080/00173134.2012.700727

8. Skjøth CA, Smith M, Brandt J, Emberlin J. Are the birch trees in southern England a source of Betula pollen for north London? Int J Biometeorol. 2009;53:75-86. http://dx.doi.org/10.1007/s00484-008-0192-1

9. Adams-Groom B, Emberlin J, Corden J, Millington W, Mullins J. Predicting the start of the birch pollen season at London, Derby and Cardiff, United Kingdom, using a multiple regression model, based on data from 1987 to 1997. Aerobiologia. 2002;18:117-123. http:// dx.doi.org/10.1023/A:1020698023134

10. Myszkowska D. Prediction of the birch pollen season characteristics in Cracow, Poland using an 18-year data series. Aerobiologia. 2013;29:31-44. http://dx.doi.org/10.1007/s10453-012-9260-4

11. Hernandez-Ceballos MA, Skjøth CA, Garcia-Mozo H, Bolivar JP, Galan C. Improvement in the accuracy of back trajectories using WRF to identify pollen sources in southern Iberian Peninsula. Int J Biometeorol. 2014;58:2031-2043. http://dx.doi.org/10.1007/ s00484-014-0804-X

12. Veriankaite L, Siljamo P, Sofiev M, Sauliene I, Kukkonen J. Modelling analysis of source regions of long-range transported birch pollen that influences allergenic seasons in Lithuania. Aerobiologia. 2010;26:47-62. http://dx.doi.org/10.1007/s10453-009-9142-6

13. Sofiev M, Siljamo P, Ranta H, Rantio-Lehtimaki A. Towards numerical forecasting of long-range air transport of birch pollen: theoretical considerations and a feasibility study. Int J Biometeorol. 2006;50:392-402. http://dx.doi.org/10.1007/s00484-006-0027-x

14. Mahura A, Korsholm U, Baklanov A, Rasmussen A. Elevated birch pollen episodes in Denmark: contributions from remote sources. Aerobiologia. 2007;23:171-179. http://dx.doi.org/10.1007/s10453-007-9061-3

15. Skjøth CA, Sommer J, Stach A, Smith M, Brandt J. The long range transport of birch (Betula) pollen from Poland and Germany causes significant pre-season concentrations in Denmark. Clin Exp Allergy. 2007;37:1204-1212. http://dx.doi. org/10.1111/j.1365-2222.2007.02771.x

16. Skjøth CA, Sommer J, Brandt J, Hvidberg M, Geels C, Hansen K, 
et al. Copenhagen - a significant source of birch (Betula) pollen? Int J Biometeorol. 2008;52:453-462. http://dx.doi.org/10.1007/ s00484-007-0139-y

17. Skjøth CA, Baker P, Sadys M, Adams-Groom B. Pollen from alder (Alnus sp.), birch (Betula sp.) and oak (Quercus sp.) in the UK originate from small woodlands. Urban Climate. 2015;14:414-428. http://dx.doi. org/10.1016/j.uclim.2014.09.007

18. Linkosalo T, Ranta H, Oksanen A, Siljamo P, Luomajoki A, Kukkonen $\mathrm{J}$, et al. A double-threshold temperature sum model for predicting the flowering duration and relative intensity of Betula pendula and B. pubescens. Agric For Meteorol. 2010;150:1579-1584. http://dx.doi. org/10.1016/j.agrformet.2010.08.007

19. Sakalli A. How can effect the synergy of climate change, soil units and vegetation groups the potential global distribution of plants up to 2300 : a modelling study for prediction of potential global distribution and migration of the $\mathrm{N}_{2}$ fixing species Alnus spp. Biogeosciences Discuss. 2015;12:815-864. http://dx.doi.org/10.5194/bgd-12-815-2015

20. Hickler T, Vohland K, Feehan J, Miller PA, Smith B, Costa L, et al. Projecting the future distribution of European potential natural vegetation zones with a generalized, tree species-based dynamic vegetation model. Global Ecology and Biogeography. 2012;21:50-63. http://dx.doi.org/10.1111/j.1466-8238.2010.00613.x

21. Newnham RM, Sparks TH, Skjøth CA, Head K, Adams-Groom B, Smith M. Pollen season and climate: Is the timing of birch pollen release in the UK approaching its limit? Int J Biometeorol. 2013;57:391-400. http://dx.doi.org/10.1007/s00484-012-0563-5

22. Frenguelli G, Bricchi E. The use of the pheno-climatic model for forecasting the pollination of some arboreal taxa. Aerobiologia. 1998;14:39-44. http://dx.doi.org/10.1007/BF02694593

23. Kasprzyk I. Flowering phenology and airborne pollen grains of chosen tree taxa in Rzeszów (SE Poland). Aerobiologia. 2003;19:113-120. http://dx.doi.org/10.1023/A:1024406819444

24. Hirst J. M. An automatic volumetric spore trap. Ann Appl Biol. 1952;39:257-265. http://dx.doi.org/10.1111/j.1744-7348.1952. tb00904.x

25. Malkiewicz M, Klaczak K, Drzeniecka-Osiadacz A, Krynicka J, Migała $\mathrm{K}$. Types of Artemisia pollen season depending on the weather conditions in Wrocław (Poland), 2002-2011. Aerobiologia. 2014;30:13-23. http://dx.doi.org/10.1007/s10453-013-9304-4

26. Kasprzyk I. Non-native Ambrosia pollen in the atmosphere of Rzeszów (SE Poland), evaluation of the effect of weather conditions on daily concentrations and starting dates of the pollen season. Int J Biometeorol. 2008;52:41-351. http://dx.doi.org/10.1007/s00484-007-0129-0

27. Makra L, Santa T, Matyasovszky I, Damialis A, Karatzas K, Bergmann $\mathrm{KC}$, et al. Airborne pollen in three European cities: detection of atmospheric circulation pathways by applying three-dimensional clustering of backward trajectories. J Geophys Res. 2010;115. http:// dx.doi.org/10.1029/2010JD014743

28. Käpyla M, Penttinen A. An evaluation of the microscopial counting methods of the tape in Hirst-Burkard pollen and spore trap. Grana. 1981;20:131-141. http://dx.doi.org/10.1080/00173138109427653

29. Goldberg C, Buch H, Moseholm L, Weeke ER. Airborne pollen records in Denmark, 1977-1986. Grana. 1988;27:209-217. http:// dx.doi.org/10.1080/00173138809428928

30. Kasprzyk I, Myszkowska D, Grewling Ł, Stach A, Šikoparija B, Skjøth CA, et al. The occurrence of Ambrosia pollen in Rzeszów, Kraków and Poznań, Poland: investigation of trends and possible transport of Ambrosia pollen from Ukraine. Int J Biometeorol. 2011;55:633-644. http://dx.doi.org/10.1007/s00484-010-0376-3

31. Skjøth CA, Sommer J, Frederiksen L, Gosewinkel Karlson U. Crop harvest in Denmark and Central Europe contributes to the local load of airborne Alternaria spore concentrations in Copenhagen. Atmos Chem Phys. 2012;12:11107-11123. http://dx.doi.org/10.5194/ acp-12-11107-2012

32. Draxler R, Hess GD. An overview of the HYSPLIT_4 modeling system of trajectories, dispersion, and deposition. Australian Meteorological Magazine. 1998;47:295-308.
33. Draxler R, Stunder B, Rolph G, Stein A, Taylor A. Hysplit4 users guide, revision September 2014 [Internet]. 2014 [cited 2015 Sep 11]; Available from: http://www.arl.noaa.gov/documents/reports/ hysplit_user_guide.pdf

34. Fernández-Rodríguez S, Sadyś M, Smith M, Tormo-Molina R, Skjøth CA, Maya-Manzano JM, et al. Potential sources of airborne Alternaria spp. spores in south-west Spain. Sci Total Environ. 2015;533:165-176. http://dx.doi.org/10.1016/j.scitotenv.2015.06.031

35. Stach A, Smith M, Skjøth CA, Brandt J. Examining Ambrosia pollen episodes at Poznañ (Poland) using back-trajectory analysis. Int J Biometeorol. 2007;51:275-286. http://dx.doi.org/10.1007/ s00484-006-0068-1

36. Šikoparija B, Smith M, Skjøth CA, Radišić P, Milkovska, S, Šimić et al. The Pannonian plain as a source of Ambrosia pollen in the Balkans. Int J Biometeorol. 2009;53:263-272. http://dx.doi.org/10.1007/ s00484-009-0212-9

37. Stach A, Emberlin J, Smith M, Adams-Groom B, Myszkowska D. Factors that determine the severity of Betula spp. pollen seasons in Poland (Poznan and Krakow) and the United Kingdom (Worcester and London), Int J Biometeorol. 2008;52:311-321. http://dx.doi. org/10.1007/s00484-007-0127-2

38. Pauling A, Rotach MW, Gehrig R, Clot C. A method to derive vegetation distribution maps for pollen dispersion models using birch as an example. Int J Biometeorol. 2012;56:949-958. http://dx.doi. org/10.1007/s00484-011-0505-7

39. Siljamo P, Sofiev M, Filatova E, Grewling E, Jäger S, Khoreva E, et al. A numerical model of birch pollen emission and dispersion in the atmosphere. Model evaluation and sensitivity analysis. Int J Biometeorol. 2013;57:125-136. http://dx.doi.org/10.1007/s00484-012-0539-5

40. Brus DJ, Hengeveld GM, Walvoort DJJ, Goedhart PW, Heidema AH, Nabuurs GJ, et al. Statistical mapping of tree species over Europe. Eur J For Res. 2011:145-157.

41. Skjøth CA, Geels C, Hvidberg M, Hertel O, Brandt J, Frohn LM, et al. An inventory of tree species in Europe - an essential data input for air pollution modelling. Ecol Modell. 2008;217:292-304. http:// dx.doi.org/10.1016/j.ecolmodel.2008.06.023

42. Estrella N, Menzel A, Krämer U, Behrendt H. Integration of flowering dates in phenology and pollen counts in aerobiology: analysis of their spatial and temporal coherence in Germany (1992-1999). Int J Biometeorol. 2006;51:49-59. http://dx.doi.org/10.1007/s00484-006-0038-7

43. Khwarahm N, Dash J, Atkinson P, Newnham RM, Skjøth CA, AdamsGroom B, et al. Exploring the spatio-temporal relationship between two key aeroallergens and meteorological variables in the United Kingdom. Int J Biometeorol. 2014;58:529-545. http://dx.doi.org/10.1007/ s00484-013-0739-7

44. Pauling A, Gehrig R, Clot B. Toward optimized temperature sum parameterizations for forecasting the start of the pollen season. Aerobiologia. 2014;30:45-57. http://dx.doi.org/10.1007/s10453-013-9308-0

45. Latalowa M, Mietus M, Uruska A. Seasonal variations in the atmospheric Betula pollen count in Gdansk (southern Baltic coast) in relation to meteorological parameters. Aerobiologia. 2002;18:33-43. http://dx.doi.org/10.1023/A:1014905611834

46. Dahl Å, Galán C, Hajkova L, Pauling A, Sikoparija B, Smith M, et al. The onset, course and intensity of the pollen season. In: Sofiev M, Bergmann KC, editors. Allergenic pollen: a review of the production, release, distribution and health impacts. Dordrecht: Springer; 2013. p. 29-70. http://dx.doi.org/10.1007/978-94-007-4881-1_3

47. Piotrowska K, Kaszewski BM. Variations in birch pollen (Betula spp.) seasons in Lublin and correlations with meteorological factors in the period 2001-2010. A preliminary study. Acta Agrobot. 2011;64(2);39-50. http://dx.doi.org/10.5586/aa.2011.016

48. Sofiev M, Berger U, Prank M, Vira J, Arteta J, Belmonte J, et al. MACC regional multi-model ensemble simulations of birch pollen dispersion in Europe. Atmos Chem Phys Discuss. 2015;15:8243-8281. http:// dx.doi.org/10.5194/acpd-15-8243-2015 


\section{Obszary źródłowe pyłku olszy (Alnus) i brzozy \\ (Betula) w Wielkiej Brytanii (Worcester) \\ i Polsce (Wrocław), w latach 2005-2012}

\section{Streszczenie}

Praca dotyczy dobowych stężeń pyłku olszy (Alnus spp.) oraz brzozy (Betula spp.) notowanych w Worcester (Wielka Brytania) oraz we Wrocławiu (Polska). Przeanalizowano sezonowość, indeks pyłkowy oraz obszary źródłowe pyłku przy zastosowaniu modelu HYSPLIT (hybrid single particle Lagrangian integrated trajectory model). W badaniu uwzględniono dane pomiarowe $\mathrm{z}$ okres 10 lat (2005-2014). Zaobserwowano istotne różnice w sezonowości, indeksie pyłkowym oraz obszarach źródłowych dla dwóch analizowanych lokalizacji. Zarówno dla olszy, jak i dla brzozy, stężenia pyłku są na ogół znacznie wyższe i sezon pyłkowy jest krótszy we Wrocławiu, stąd też jest on bardziej intensywny, niż w Worcester. Wynika to najprawdopodobniej $\mathrm{z}$ różnic $\mathrm{w}$ warunkach klimatycznych pomiędzy dwoma stacjami i z większej liczby lokalnych źródeł pyłku w Polsce niż w Anglii. Obliczenia przeprowadzone z modelem HYSPLIT wskazują, że źródłem ziaren pyłku są głównie drzewa lokalne, ale zaznacza się również rola transportu odległego, ale w szczególności w przypadku pyłku brzozy, a tylko w niewielkim stopniu w przypadku olszy. W przypadku brzozy, na stężenie pyłku notowanego w obu stacjach istotnie wpływa pyłek pochodzący z obszaru Niemiec, Holandii i Belgii, podczas gdy powszechnie znane obszary źródłowe w Rosji, Białorusi i Skandynawii mają bardzo ograniczony wpływ na stężenie pyłku w Worcester i we Wrocławiu. Ponadto zaobserwowano wyraźne, systematyczne zróżnicowanie indeksu pyłkowego brzozy we Wrocławiu, z wysokimi wartościami występującymi co drugi rok. Podobna zależność nie jest obserwowana dla Worcester. Wyraźnych zróżnicowań indeksu pyłkowego pomiędzy latami nie notowano dla olszy w żadnej z lokalizacji. 